\title{
ULCERUL GASTRIC DUPĂ ADMINISTRAREA PE TERMEN SCURT DE ANTIINFLAMATOARE NESTEROIDIENE LA UN COPIL MIC - PREZENTARE DE CAZ
}

\author{
Ancuța Ignat' ${ }^{1}$, Gabriela Păduraru ${ }^{1}$, Angelica Cristina Marin ${ }^{1}$, \\ Anamaria Ciubară ${ }^{2}$, Valeriu V. Lupu ${ }^{1}$, Marin Burlea ${ }^{1}$ \\ ${ }^{1}$ Disciplina Pediatrie, Universitatea de Medicină şi Farmacie „, Gr. T. Popa “, Iaşi \\ ${ }^{2}$ Disciplina Psihiatrie, Universitatea de Medicină şi Farmacie ,, Gr. T. Popa “, Iaşi
}

\begin{abstract}
REZUMAT
Agenții antiinflamatori nesteroidieni (AINS) produc leziuni gastrice prin intermediul a două mecanisme: iritația locală şi acțiunea sistemică. Un copil în vârstă de 2 ani şi 10 luni, sex feminin, a primit AINS timp de 2 zile pentru o infecție acută a tractului respirator superior şi a prezentat vărsături în „zaț de cafea“ o zi mai târziu. Endoscopia digestivă superioară a evidențiat o leziune de ulcer gastric. Biopsia gastrică a fost negativă pentru infecția cu H. pylori, iar pacienta a fost diagnosticată cu ulcer gastric acut indus de consumul de AINS în absența altor cauze de ulcer gastric. Ulcerele gastrice se dezvoltă foarte rar după o administrare pe termen scurt de AINS, fapt ce a determinat raportarea acestui caz. Luând în considerare atât riscurile cât şi beneficiile terapiei cu AINS, este indicat ca în cazul fiecărui pacient care trebuie să urmeze un tratament cronic cu medicamente antiinflamatorii să fie căutați posibilii factori de risc asociați.
\end{abstract}

Cuvinte cheie: medicamente antiinflamatoare nesteroidiene (AINS), ulcer gastric, copil

\section{INTRODUCERE}

Hemoragia gastrointestinală este una dintre cele mai grave probleme care trebuie diagnosticate şi tratate de către gastroenterologul pediatru. Hemoragiile gastrointestinale severe sunt rare la populația pediatrică şi, prin urmare, acestea nu sunt foarte bine documentate. (1)

Ulcerul gastric reprezintă o boală multifactorială şi constă în pierderea bine delimitată de țesut ce cuprinde atât mucoasa, submucoasa cât şi musculara gastrică. Acesta este rezultatul unui dezechilibru dintre mecanismele de protecție ale mucoasei şi factorii agresivi ce acționează asupra ei. (2)

Agenții antiinflamatori nesteroidieni (AINS) reprezintă un grup heterogen de substanţe chimice care acționează asupra anumitor etape ale răspunsului inflamator pentru a le reduce din intensitate. În practica pediatrică ele sunt frecvent utilizate la copiii mici pentru reducerea febrei sau controlul durerii. Dozele mari sau utilizarea prelungită sunt asociate cu numeroase complicații gastrointestinale. AINS produc leziuni gastrice prin intermediul a două mecanisme: iritația locală şi acțiunea sistemică. Ulcerele gastrice induse de AINS apar mai ales în antrumul gastric şi sunt caracterizate prin: sunt multiple, de formă neregulată, extinse în profunzime sau ca suprafață. $\mathrm{Cu}$ toate acestea, cele extinse în profunzime sau ca suprafață se dezvoltă de obicei în timpul administrării pe termen lung de AINS. $(3,4)$

\section{PREZENTARE DE CAZ}

Pacientă de sex feminin, în vârstă de 2 ani şi 10 luni, ce a primit AINS pentru o infecție acută a tractului respirator superior, timp de 2 zile, a prezentat o zi mai târziu vărsături în „zaț de cafea“ şi dureri epigastrice, motiv pentru care s-a internat în clinica de gastroenterologie pediatrică. 
Anamneza a relevat prezența unei boli respiratorii a cărei simptomatologie a debutat cu 48 de ore anterior internării şi care a fost tratată simptomatic la domiciliu cu ibuprofen -3 doze de $150 \mathrm{mg} / 8 \mathrm{~h}$. Pacienta nu primea medicaţie de fond pentru alte afecțiuni cronice. Din istoric reținem că nu a mai prezentat episoade dispeptice chiar dacă în perioada de sugar i-au mai fost administrate doze izolate de ibuprofen. În familie nu au existat membri diagnosticați cu ulcere gastroduodenale sau infecție cu Helicobacter pylori.

Examenul fizic a relevat o stare generală influențată, tegumente palide şi deshidratate, facies suferind, congestie faringiană şi abdomen destins, sensibil la palparea superficială și profundă cu intensitate maximă în epigastru. În timpul spitalizării a prezentat episoade dispeptice însoțite de hematemeză şi dureri epigastrice.

Investigațiile de laborator au arătat prezența unui sindrom de hepatocitoliză minor, însă testele de coagulare şi ecografia abdominală au fost normale.

Endoscopia digestivă superioară a evidențiat în zona antrală prepilorică o ulcerație ovoidală cu di-
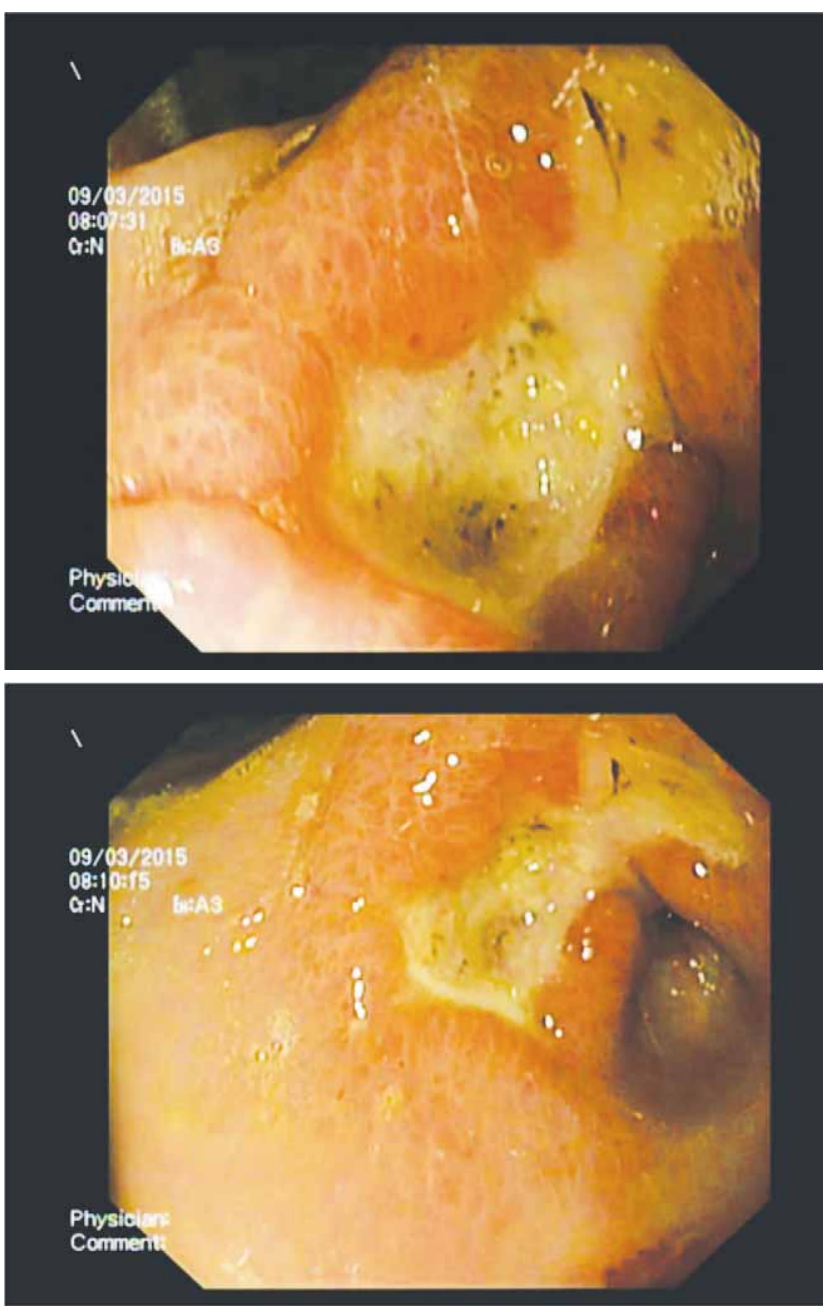

FIGURA 1. Endoscopie digestivă superioară: ulcer prepiloric ovoidal de $2 / 3 \mathrm{~cm}$ mensiuni de $2 / 3 \mathrm{~cm}$, la $2 \mathrm{~cm}$ de pilor, mucoasă gastrică antrală purpurică şi lichid de stază cu resturi alimentare (Fig. 1). Testul rapid al ureazei şi examenul microscopic direct au fost negative pentru Helicobacter pylori.

Copilul a primit hemostatice şi IPP pe cale intravenoasă, urmate de IPP administrate oral. Pacienta a fost externată după 6 zile cu următorul tratament: IPP oral (Esomeprazol $1 \mathrm{mg} / \mathrm{kgc} / \mathrm{zi}$ ) timp de şase săptămâni. Evoluția a fost favorabilă după tratamentul dietetic şi medicamentos.

Particularitatea cazului constă în vârsta mică a pacientului şi complicaţia digestivă precoce la doza recomandată de AINS în absența altor factori de risc.

\section{DISCUȚII}

Vărsătura în ,zaț de cafea“ reprezintă rezultatul unui contact îndelungat între sânge şi sucul gastric, fapt ce permite transformarea hemoglobinei în clorhidrat de hematină sub acțiunea acidului clorhidric. Conţinutul gastric ce conţine sânge roşu este dovada unei hemoragii active, care determină un contact de scurtă durată a sângelui cu sucul gastric.

Hemoragiile gastrointestinale la sugari şi copii sunt o problemă destul de comună, reprezentând $10-20 \%$ din vizitele la pediatrul gastroenterolog. $\mathrm{Cu}$ toate acestea, sunt de obicei limitate în volum, necesitând un timp îndelungat pentru diagnostic şi tratament. (1)

Etiologia hemoragiilor digestive superioare la copii este cu siguranță legată de vârstă. Ulcerul gastro-duodenal, gastrita (datorată stresului sau medicamentelor), varicele, epistaxisul, sindromul Mallory-Weiss sunt cele mai comune etiologii la copiii cu vârste cuprinse între 3-5 ani. $(2,5)$

Medicamente cum ar fi AINS, steroizi şi antibiotice, care generează de multe ori deteriorarea mucoaselor, cauzează hemoragii şi cresc riscul, în cazul în care există antecedente de utilizare cronică de medicamente, precum anticonvulsivantele sau antibioticele pe cale orală administrate pe termen lung. Utilizarea prelungită a AINS este asociată cu tulburări gastro-intestinale: gastrite, ulcere, sângerări gastro-intestinale. (6)

La adulții cu terapie cronică cu AINS, ulcerul gastric detectat prin endoscopie are un procent de 15-30\%. (7) Dintre copiii cu simptome digestive, sub tratament cronic cu AINS pentru poliartrită reumatoidă, peste $75 \%$ prezintă leziuni endoscopice antrale şi ulcere. (8)

Două mecanisme sunt menţionate ca fiind implicate într-o manieră sinergică în producerea de leziuni ale mucoasei gastrice: AINS dobândesc capa- 
citatea de a impregna membranele celulare într-un mediu acid şi se acumulează în celulele epiteliale rezultând tulburări metabolice ce duc la perturbarea celulară şi inhibarea ciclooxigenazei de către AINS, o scădere a producției de prostaglandine endogene (PG) şi a factorilor protectori cu rol major în apărarea mucoasei gastrice, fapt ce favorizează apariția unor leziuni ale mucoasei. (9)

Studii comparative la copiii şi adolescenţii tratați cu acetaminofen/AINS au ajuns la concluzia că hemoragiile gastrointestinale apar doar la pacienții la care au fost administrate AINS. Factorii asociați cu utilizarea de AINS în determinarea complicațiilor gastrointestinale sunt: ulcere preexistente, doze multiple sau mari de AINS, comorbidități (poliartrita reumatoidă), corticosteroizi sau anticoagulante, infecția cu Helicobacter pylori. $(2,10)$

S-a observat, de asemenea, că un precursor AINS poate reduce producția de $\mathrm{PG}$, iar refluxul duodenogastric al componentei sale active (excretată din ficat în bilă) este implicat în mecanismul producerii de leziuni ale mucoasei gastrice. Leziuni ale mucoasei gastrice induse de AINS pot apărea în orice moment după începerea tratamentului. (11)

Date clinice, dar mai ales calitatea tot mai mare şi acuratețea diagnosticului de laborator conduc la o rată scăzută a complicațiilor acestor boli prin aplicarea strategiilor de tratament multimodal şi îmbunătățirea lor în mod constant.

\section{CONCLUZII}

Copiii cu vârste sub 36 de luni au un risc relativ crescut de a dezvolta hemoragii gastro-intestinale după administrarea primei doze de AINS.

Acetaminofenul este mai sigur atunci când este utilizat ca medicament de primă intenție pentru controlul febrei la copii.

Particularități individuale ale metabolismului AINS, dependente de vârstă şi/sau enzimatice, pot favoriza complicații digestive cu debut precoce la doze corespunzătoare vârstei. 